\title{
Comparison of Coronary Artery Bypass Surgery Results in Patients under 40 and over 80
}

\author{
Hasan Uncu, Tolga Onur Badak, Haci Ali Ucak, Ibrahim Ozsoyler \\ Cardiovascular Surgery, Adana Numune Training and Research Hospital, Adana, Turkey \\ Email: haliucak@gmail.com, ibrahimozsoyler@yahoo.com, tolgaonurbadak dr@hotmail.com, \\ hasan uncu70@hotmail.com
}

Received 11 February 2015; accepted 2 April 2015; published 8 April 2015

Copyright (C) 2015 by authors and Scientific Research Publishing Inc.

This work is licensed under the Creative Commons Attribution International License (CC BY). http://creativecommons.org/licenses/by/4.0/ (c) () D Den Access

\begin{abstract}
Purpose: Coronary artery disease incidence under 40 years age is increasing parallel with atherosclerotic disease at the present day while it's seen frequently over 40 . We compared the preoperative risk factors and early postoperative results of patients under 40 years age with those over 80 years age executed coronary artery bypass surgery in our clinic in this retrospective study. Patients and method: 128 patients (106 patients under 40 years age (Group 1) and 22 patients aged over 80 (Group 2)) executed coronary artery bypass surgery between January 2004 and June 2012 in our clinic are included in this study. Result: Mean age was 45.2 \pm 17.2 . Smoking, diabetes mellitus and high low density lipoprotein levels were the predisposing risk factors in Group 1 while hypertension and chronic obstructive pulmonary disease are predominated in the other. All patients are taken to surgical procedure under elective conditions. Aortic cross clamp duration were $37.02 \pm 16.2$ and $38.9 \pm 13.5$ minutes respectively; total cardiopulmonary bypass interval was $67.1 \pm 26.3$ minutes. Utilization of left internal mammarian artery was significantly higher (p $=0.01$ ) in group 1 when compared in terms of graft management. Necessity of positive inotropic support $(p=0.033)$ and intraaortic balloon pump demand $(p=0.315)$ are found higher in Group 2. Atrial fibrillation, neurologic complications, delirium, wound infection, and postoperative revision demand are found significantly low $(p=0.136)$ in Group 1 . There was no mortality in both groups. Discussion: Postoperative complications are seen more often in the elder group, while there was no significant difference in terms of mortality in both groups. Coronary revascularisation is safely practical in both young and elder patients with well early postoperative results and acceptable hospital mortality.
\end{abstract}

\section{Keywords}

CAD, Aged under 40, over 80, Coronary Artery Bypass Surgery 


\section{Introduction}

Coronary artery disease is one of the most important and predominating means of fatality in this world. CAD is ordinarily seen over 40 years and elder patients; however, coronary artery bypass surgery is reported as an exponential procedure among patients aged under 40 and over 80 years parallel with ascending atherosclerosis both in our country and internationally [1]-[3]. Multiple risk factors for atherosclerosis are established in CAD patients manifesting with myocardial infarction such as smoking [4] [5], family history [4]-[7], hypercholesteremia [5] [6], diabetes mellitus [4] [7], hypertension [4]-[6], obesity [5] [7], oral contraceptive utilisation in young females [8], cocain addiction [9], etc. Higher mortality and morbidity rates of coronary artery bypass surgery procedures in the elder patients is a matter of common knowledge in literatüre [10] [11]. We aimed to discuss preoperative risk factors and early postoperative results of 128 patients under 40 and over 80 years age executed coronary artery bypass surgery in our clinic under demographic values retrospectively.

\section{Material and Method}

A total of 128 patients, 106 under 40 years age (Group 1); 22 over 80 years age (Group 2) executed coronary artery bypass surgery under cardiopulmonary bypass and elective conditions are choosen from the 5527 cardiac surgery executed patients between January 2004 and June 2012 in our clinic for this study. The ethical committee review board of both participating institutions approved the study, and all patients provided informed consent. Patients executed additional procedures as vascular; valvular or septal repair surgery and beating heart coronary artery surgery are omitted from this study.

Parameters as diabetes mellitus (DM), hypertension (Ht), chronic obstructive pulmonary disease (COPD), LDL levels, blood amount transfused postoperatively, duration of coronary care unit and hospitalisation period, aortic cross clamp time,, total cardiopulmonary bypass time, utilisation of left internal mammarian artery (LIMA); amount of mediastinal drainage, utilisation of intraaortic balloon pump; postoperative early atrial fibrillation (AF), delirium arising and mortality are discussed in both groups.

\subsection{Surgical Procedure}

All patients are taken to surgery under elective conditions. Arterial cannula insertion to ascending aorta, two stage venous cannula insertion to right atrium for cardiopulmonary bypass were our routines in coronary artery bypass grafting procedures. Cardiopulmonary bypass resumed after heparinisation ( $3 \mathrm{mg} / \mathrm{kg}$ intravenously). Membrane oxygenator is utilised and non pulsatile flow is maintained from a ruller pump during cardiopulmonary bypass. Moderate hemodilution (hematocrit level 22\% - 24\%) and mild hypothermia (nasopharyngeal temprature $32^{\circ} \mathrm{C}$ ) are maintained. A pump flow of $2.4 \mathrm{lt} / \mathrm{m}^{2} / \mathrm{min}$ and blood pressure over $60 \mathrm{mmHg}$ are maintained during cardiopulmonary bypass. Myocardial protection after placing the aortic cross clamp and cardiac arrest is maintained by mild systemic hypothermia and blood cardioplegia with potassium $(10 \mathrm{ml} / \mathrm{kg})$ given through the aortic root. $250 \mathrm{ml}$ of cardioplegia is given through each graft after distal anastomosis. Cold saline solution $\left(+4^{\circ} \mathrm{C}\right)$ is used for cooling the myocardium. LIMA grafts are anastomosed to LAD artery. Proximal anastomosis of all grafts are performed under partial clamp on the beating heart.

All of the patients are extubated between 2 - 12 hours. Extubation criteria were hourly drainage under acceptable levels and haemodynamic stability besides full consciousness. Hospital mortality is accepted as the first 30 days.

\subsection{Statistical Analysis}

İstatistiksel analiz SPSS 13.0 (Statistical Package for the Social Sciences) kullanilarak yapildi. Sonuçlarin değerlendirilmesinde ortalama \pm standart sapma (minimum ve maksimum), kategorik değişkenler için Mann-Whitney U testi, sürekli değişkenler için T testi kullanildi.

Statistical Analysis: Statistical analysis is performed by SPSS 13.0 (Statistical Package for the Social Sciences). Mean average \pm standart deviation is used in revealing the results; $T$ test for continuous variables, and Mann-Whitney U test for categorized variables.

\section{Results}

One patient in both groups needed intraaortic balloon support besides the positive inotropic agent infusion for 
low cardiac output (LCO) in the postoperative period (Table 1). Atrial fibrillation is detected in 5 (4.7\%) patients in Group 1 and in $3(13.6 \%)$ patients in Group 2 in early postoperative period $(p=0.138)$. All these patients respond to medical therapy and sinusal rythm is maintained. The overall mediastinal and thoracic total drainage was $425.3 \pm 175.0 \mathrm{ml}$. In 24 hours; 2 patients in both groups (1.8\% and 9.1\%) are reoperated for bleeding. The overall blood transfussed was $1.2 \pm 1.1$ units. Mean average extubation period was $4.5 \pm 1.9$ hours. There was no neurologic deficit in Group 1 but in 1 (4.5\%) patient in Group 2; delirium detected in 4 (3.7\%) patients in Group 1 and in 8 (36\%) patients in Group 2; no wound infection in Groups 1 and 2 (4.5) wound infections in Group 2 (Table 2). Major neurologic complicated patient in Group 2 was hospitalised for an extended 20 days, there no mortality for these reasons. Duration of stay in the intensive care unit was $1-15$ (mean $1.3 \pm 1.3$ ) days. Total hospitalisation time was 4 - 20 (mean $4.7 \pm 1.9$ ) days. There were no hospital mortality in patients subject to this study.

\section{Findings}

Mean age was $45.2 \pm 17.2$, there were 87 (82.1\%) male and 19 (17.9\%) female patients in Group 1 where as 17 (77.3\%) male and 5 (22.7\%) female in Group 2. Preoperative demographic properties of the patients are shown in Table 3.

Table 1. Postoperative data.

\begin{tabular}{ccc}
\hline & Mean \pm SD & Range \\
\hline Drenage (ml) & 425 & $(100-1050)$ \\
MICUS (days) & 1.3 & $(1-15)$ \\
MHS (days) & 4.7 & $(4-20)$ \\
VT (hours) & 4.5 & $(2-12)$ \\
Transfusion (unit) & 1.2 & $\%$ \\
Inotrop support (n) & $\mathrm{n}$ & 50 \\
IABP (n) & 64 & 1.5 \\
Mortalite (n) & 2 & 0 \\
\hline
\end{tabular}

MICUS: mean intensive care unit stay; MHS: mean hospital stay; IABP: intra-aortic baloon pump; VT: ventilation time; OKT: Ortalama kan transfüzyonu.

Table 2. Postoperative complications.

\begin{tabular}{|c|c|c|c|c|c|}
\hline & \multicolumn{2}{|c|}{ Group 1} & \multicolumn{2}{|c|}{ Group 2} & \multirow[b]{2}{*}{$\mathbf{p}$} \\
\hline & $\mathbf{n}$ & $\%$ & Sayi & $\%$ & \\
\hline Reoperation & 2 & 1.8 & 2 & 9.0 & 0.136 \\
\hline Sternal dehiscence & 0 & - & 0 & - & - \\
\hline Reintubation & 0 & - & 0 & - & - \\
\hline CVD & 0 & - & 1 & 4.5 & 0.172 \\
\hline Delirium & 4 & 37.7 & 3 & 13.6 & 0.000 \\
\hline Sleep disorder & 3 & 2.8 & 4 & 18.2 & 0.017 \\
\hline $\mathrm{AF}$ & 5 & 4.7 & 3 & 13.6 & 0.138 \\
\hline Wound infection & 0 & - & 1 & 4.5 & 0.172 \\
\hline
\end{tabular}

CVO: cerebrovascular disorders; AF: atrial fibrillation. 
Tablo 3. Preoperative characteristics.

\begin{tabular}{|c|c|c|c|c|c|}
\hline \multirow[b]{2}{*}{ Risk faktörleri } & \multicolumn{2}{|c|}{ Group 1} & \multicolumn{2}{|c|}{ Group 2} & \multirow[t]{2}{*}{ Mean } \\
\hline & $\mathbf{n}$ & $\%$ & $\mathbf{n}$ & $\%$ & \\
\hline Age & & & & & 45.2 \\
\hline \multicolumn{6}{|l|}{ Gender } \\
\hline Male & 87 & 82.1 & 17 & 77.3 & \\
\hline Female & 19 & 77.3 & 5 & 22.7 & \\
\hline DM & 32 & 30.1 & 5 & 22.7 & \\
\hline HT & 21 & 19.8 & 9 & 40.9 & \\
\hline Smoking & 63 & 59.4 & 12 & 54.5 & \\
\hline COPD & 4 & 3.7 & 3 & 13.6 & \\
\hline Ejection fraction (EF) (\%) & & & & & 53.5 \\
\hline
\end{tabular}

LIMA graft was utilized in 96 (90.5\%) patients in Group 1 and in 14 (63.6\%) patients in Group 2. Aortic cross clamp periods were $37.02 \pm 16.26$ and $38.90 \pm 13.58$ respectively. Total cardiopulmonary bypass period were $66.8 \pm 25.9$ minutes in Group 1 and $69.04 \pm 29.33$ minutes in Group 2 with a mean as $67.17 \pm 26.39$.

\section{Discussion}

Cardiovascular diseaes incidental upon atherosclerosis ascending in our country likewise all on the world is enhancing the number of patients convicted to cardiovascular operations. Coronary heart disease is the primary reason of death in our country which also raises us to upper stairs in whole Europe. Cardiovascular risk factors should have to be decreased under control in order to reduce coronary heart disease and other cardiovascular disease and relative frequency of mortality. Hypertension, hyperlipidemia, diabetes mellitus and smoking are the main risk factors which can be modified, whereas age is the most important factor which cant be modified [12]. Early lesions of atherosclerosis may be visible even in childhood, but obvious coronary heart disease emerges in advanced ages and expands with every decade [13]. Evaluation of risk factors reveals smoking and diabetes mellitus in Group 1; hypertension and hyperlipidemia in Group 2 are found eminent in our study. Ht and hyperlipidemia are increasing with age in the population, thats why we see these diseases ordinarily higher in Group 2.

Coronary artery disease is more frequent in males than in females. The majör cause is Males are prone to atherosclerosis more than females. Protective hormonal barrier diminishes after menopause and risk of CAD in both sexes are equalized after menopause [13]. The patients in Group 1 were $82 \%$ male, $17.9 \%$ female and $77.3 \%$ male, 22.7\% female in Group $2(\mathrm{p}=0.396)$. Our study shows that incidence of CAD is increasing with age in females consistently with the literatüre.

The mostly utilized grafts in coronary artery bypass surgery are LIMA and the saphenous veins. Its known that long term patency rates of arterial grafts are higher than saphenous vein grafts. Utilization of LIMA for revascularisation of LAD is a golden standart [14]. LIMA graft have been utilized in 96 patients (90.5\%) in Group 1 and in 14 patients (63.6) in Group 2. Peripheral iliac artery disease in 3 patients and low blood flow in LIMA after exploration in 5 patients avoided utilization of LIMA.

Low cardiac output and rythm problems (atrial fibrillation; ventricular extrasystoles etc.) emerging after coronary artery bypass surgery are important means of morbidity and can prolong hospitalisation time. These complications affecting morbidity are seen barely in young patients when compared with elder group [15]. 48 patients (45.2\%) in Group 1 and 16 patients (72.7\%) in Group 2 required positive inotropic agents and 1 patient in each group ( $0.9 \%$ and $4.5 \%)$ required intraaortic balloon support. These patients had improved durations both in intensive care unit and hospitalisation period.

Arrhythmias are the most common complication postoperatively. Atrial fibrillation (AF) is the most frequently seen rythm disturbance. Atrial fibrillation is scarcely seen in young patients whereas its common in advanced ages [15]. AF incidence in our study is 5 patients (4.7\%) in Group 1 and 3 patients (13.6\%) in Group 2 respectively. We found that AF incidence in advanced age group is statistically significant $(\mathrm{p}=0.138)$ confor- 
mable with the literatüre.

Relative frequency of neurologic complication after coronary artery bypass surgery is $3 \%-5 \%$. This rate may increase up to $9 \%$ over 75 years age. Neurologic injury may have many reasons. Cerebral hypoperfusion, bleeding, air or particular embolii, extracranial carotis lesions and metabolic reasons are among aetiology. Neurologic complications accompanying after coronary bypass surgery are responsible from $21 \%$ of the mortality. Patients with neurologic complications have a meaningfully prolonged hospitalisation period which bings an economical load [16]. Intensive care unit duration of patients in both groups were $1.3 \pm 1.3$ days, with a $4.7 \pm$ 1.9 days of hospitalisation time. There were only one patient in Group 2 wited h a majör neurologic complication in this study. There were no mortality related to neurologic patients and neurological complicated patient was hospitalised for 20 more days.

Delirium is state with fluctiations in attention and consciousness. It is reported with a frequency rate of $30 \%$ after cardiac operations. Its a disorder with multiple reasons but its aetiopatology is still obscure [17]. Postoperative delirium exposing after coronary artery bypass surgery is a marker of mortality in the following 10 years after surgery. Its even a stronger marker in young patients without a history of stroke [18]. 4 patients (3.7\%) in Group 1 and 8 patients (36.3\%) in Group 2 had delirium in our study ( $\mathrm{p}=0.000$ ). We believe neurologic complications are more prominent in elder patients because they more sensitive to cerebral hypoperfusion.

Deep sternal wound infection is a rare but fatal complication of open heart surgery $(0.8 \%-5 \%)$. Causes prolonged hospitalisation, high morbidity and mortality rates. Has multiple reasons; any insufficiency in the aceptic state of the surgical equipment or the operating room is the most common cause of sternal infection. Prolonged operation time, improper closure of surgical layers, improper bleeding control, utilization of both internal thoracic arteries as bypass grafts, obesity, COPD, prolonged mechanical ventilation time, transfusions and renal insufficiency enhances the risk of sternal infection [19]. Among this study there was only 1 (4.5\%) patient in Group 2 with sternal wound infection which healed with medical treatment and was discharged safely. We believe there is no relation between age and sternal wound infection.

\section{Conclusion}

As a result, smoking and diabetes mellitus are important risk factors in patients executing coronary artery bypass surgery under 40 years age, but doesn't effects morbidity and mortality. Coronary revascularisation both in young and older patients can be carried out with well early postoperative results and acceptable hospital mortality though prolonged hospitalisation time and postoperative complications are seen more frequently in patients over 80 .

\section{References}

[1] Salomaon, N.W., Page, U.S., Bigelovv, J.C., Krause, A.H., Okies, J.E. and Mezdorg, M.T. (1991) Coronary Artery Bypass Grafting in Elderly Patients: Comparative Results in a Consecutive Series of 469 Patients Older than 75 Years. Journal of Thoracic and Cardiovascular Surgery, 101, 209-218.

[2] Galbut, D.L., Traad, E.A., Dorman, M.J., DeWitt, P.L., Larsen, P.B., Kurlansky, P.A. and Carrillo, M.G. (1993) Coronary Artery Bypass Grafting in the Elderly: Single versus Bilateral İnternal Mammary Artery Grafts. Journal of Thoracic and Cardiovascular Surgery, 106, 128-136.

[3] He, G.W., Acuff, T.E., Ryan, W.H., Brovvman, R.T., Douthit, M.B. and Mack, M.J. (1994) Determinants of Operative Mortality in Elderly Patients Undergoing Coronary Artery Bypass Grafting: Emphasis on the İnfluence of İnternal Mammary Artery Grafting on Mortality and Morbidity. Journal of Thoracic and Cardiovascular Surgery, 108, 73-81.

[4] Hoit, B.D., Gilpin, E.A., Henning, H., et al. (1986) Myocardial İnfarction in Young Patients: An Analysis by Age Subsets. Circulation, 74, 712-721. http://dx.doi.org/10.1161/01.CIR.74.4.712

[5] Noeman, A., Ahmad, N. and Azhar, M. (2007) Coronary Artery Disease in Young: Faulty Life Style or Heredofamilial or Both. Annals, 13, 162-164.

[6] Hoit, B.D., Gilpin, E.A., Henning, H., et al. (1986) Myocardial İnfarction in Young Patients: An Analysis by Age Subsets. Circulation, 74, 712-721. http://dx.doi.org/10.1161/01.CIR.74.4.712

[7] Zehr, K.J., Lee, P.C., Poston, R.S., Gillinov, A.M., Greene, P.S. and Cameron, D.E. (1994) Two Decades of Coronary Artery Bypass Graft Surgery in Young Adults. Circulation, 90, II133-II139.

[8] Rosenberg, L., Palmer, J.R., Rao, R.S. and Shapiro, S. (2001) Low-Dose Oral Contraceptive Use and the Risk of Myo- 
cardial İnfarction. Archives of Internal Medicine, 161, 1065-1070. http://dx.doi.org/10.1001/archinte.161.8.1065

[9] Qureshi, A.I., Suri, M.F., Guterman, L.R. and Hopkins, L.N. (2001) Cocaine Use and the Likelihood of Nonfatal Myocardial İnfarction and Stroke: Data from the Third National Health and Nutrition Examination Survey. Circulation, 103, 502-506. http://dx.doi.org/10.1161/01.CIR.103.4.502

[10] Albes, J.M., Schistek, R., Baier, R., Unger, A., Hangier, H. and Unger, F. (1991) Earlv and Late Results Follovving Coronary Bypass Surgery beyond the Age of 75 Years. Thoracic and Cardiovascular Surgeon, 39, $289-293$. http://dx.doi.org/10.1055/s-2007-1019988

[11] Edmunds Jr., L.H., Stephenson, L.W., Edie, R.N. and Ratcliffe, M.B. (1988) Open-Heart Surgery in Octogenerians. The New England Journal of Medicine, 319, 131-136. http://dx.doi.org/10.1056/NEJM198807213190302

[12] Abaci, A. (2011) Kardiyovasküler Risk Faktörlerinin Ülkemizdeki Durumu. Archives of the Turkish Society of Cardiology, 39, 1-5. http://dx.doi.org/10.5543/tkda.2011.abaci

[13] Kumar, V., Cotran, R. and Robbıns, S. (2000) Basic Pathology. Kumar, Cotran, Robbins Türkçesi. 283-289.

[14] Kaya, E., Mansuroğlu, D., Göksedef, D., Ömeroğlu, S.N., Toker, M.E., Kirali, K., Balkanay, M., İpek, G. and Yakut, C. (2005) Koroner Arter Bypass Cerrahisinde Birden Fazla Arteryel Greft Kullanilan Hastalarda Uzun Dönem Anjiyografik Sonuçlarin Değerlendirilmesi. Türk Göğüs Kalp Damar Cer Derg, 13, 309-313.

[15] Tokmakoğlu, H., Kandemir, Ö., Farsak, B., Günaydin, S., Yorgancioğlu, C. and Zorlutuna, Y. (2002) Genç Yaş Grubu Hastalarda Koroner Arter Bypass Cerrahisi. Journal of Thoracic and Cardiovascular Surgery, 10, 1-4.

[16] Orhan, G., Sokullu, O., Biçer, Y., Şenay, Ş., Yücel, O., Özay, B., Sargin, M. and Aka, S.A. (2007) Koroner Arter Bypass Cerrahisinde Tek Klemp Tekniğinin İnme Riski Üzerine Etkisi. Türk Gögü̈s Kalp Damar Cer Derg, 15, 45-50.

[17] Sezer, Ö., Karlidağ, R., Karabulut, A.B., Özcan, C., Nisanoğlu, V., Türköz, Y., But, A. and Ünal, S. (2004) Koroner Bypass Ameliyati Geçiren Hastalarda Deliryum Gelişiminin Nitrik Oksit Düzeyleriyle İlişkisi. Klinik Psikofarmakoloji Bülteni, 14, 185-190.

[18] Gottesman, R.F., Grega, M.A., Bailey, M.M., Pham, L.D., Zeger, S.L., Baumgartner, W.A., Selnes, O.A. and McKhann, G.M. (2010) Delirium after Coronary Artery Bypass Graft Surgery and Late Mortality. Annals of Neurology, 67, 338-344.

[19] Tünerir, B., Beşoğul, Y., Yavuz, T., Dernek, S., Sevin, B., Kural, T. and Aslan, R. (1999) Açik Kalp Cerrahisi Sonrasi Görülen Derin Sternal Enfeksiyonda Nazal Stafilokokus Aureus. Türk Gögüus Kalp Damar Cer Derg, 7, 183-186. 